$N S R P-S P C-S P 023 / 1$

\title{
SURFACE PREPARATION: \\ A COMPARATIVE ANALYSIS \\ OF EXISTING STANDARDS \\ A PROPOSED MARINE STANDARD
}

\section{AUGUST 1983}

Author. Ms. Linda Jackel

Prepared by:

INSTITUTE OF APPLIED TECHNOLOGY

In Cooperation with

Avondale Shipyards, Inc. 